\title{
En torno al personaje histórico Figuras precolombinas y coloniales en la literatura hispanoamericana de la Independencia a nuestros días
}

\author{
Beatriz Aracil Varón
}

Si bien los orígenes mismos de la creación literaria hispanoamericana pueden situarse en la plasmación de una materia histórica -la que configura el amplio corpus textual que definimos como Crónica de Indias ${ }^{1}$, lo cierto es que los procesos de Independencia y, sobre todo, de formación de las nuevas naciones intensificaron la presencia de la historia en dicha creación literaria, esto es, la reflexión sobre un pasado que pudiera -como ha apuntado Noé Jitrik- «esclarecer el enigma del presente» ${ }^{2}$.

Esta presencia destacada de la historia en la literatura que, como vemos, guarda estrecha relación con una búsqueda identitaria y que prevalece en el discurso literario latinoamericano hasta nuestros días, tiene uno de sus más claros ejemplos en el rápido surgimiento y evolución de la novela histórica en el continente. La entusiasta aceptación durante el siglo XIX del modelo iniciado por Walter Scott en Europa y su amplio desarrollo posterior hasta llegar a lo que se ha dado en llamar la «nueva novela histórica» latinoamericana se explica precisamente por un compromiso adquirido por los autores con su contexto socio-político más inmediato, compromiso que, con diversas matizaciones (sobre todo referidas a la relación con el poder y a la propia valoración de la «historia oficial»), se observa en buena medida hasta estos albores del siglo XXI, y que justificó (y justifica asimismo en la novela contemporánea, aunque desde posiciones mucho más libres y desmitificadoras), el carácter «selectivo» y crítico de la mayoría de las obras, sobre todo en lo referente a la recuperación de las raíces propias en el pasado precolombino y al olvido o la denuncia del «terrible» período colonial.

Pero además, el desarrollo de la novela histórica es también buen ejemplo de una tendencia dominante (aunque evidentemente no exclusiva) en los autores hispanoamericanos hasta nuestros días: en contra de la tradición iniciada por Scott, quien hizo protagonistas de sus novelas a «héroes mediocres»-como los definiría Lukács-, esto es, a personajes ficticios o de escasa relevancia histórica ${ }^{3}$, los escritores románticos prefirieron los personajes históricos destacados, que tenían una significación en el pasado de la comunidad y cuya trayectoria podía resultar «ejemplar» para ésta, personajes que, de alguna forma, correspondían -según sugiere Jitrik- a esa teoría ilustrada y romántica del «hombre representativo» que excede los límites de la novela y que tiene su formulación más brillante en Facundo, de José Faustino Sarmiento ${ }^{4}$.

1 Véase, entre otros, Enrique Pupo-Walker, La vocación literaria del pensamiento histórico en América, Madrid, Gredos, 1982.

2 Noé Jitrik, Historia e imaginación literaria: las posibilidades de un género, Buenos Aires, Biblos, 1995 , p. 19.

3 Capaces, según Lukács, de reflejar mejor el conflicto histórico y sus consecuencias en el pueblo (véase Georg Lukács, La novela histórica, México, Ediciones Era, 1971, en especial pp. 36-58).

4 Véase Jitrik, Historia e imaginación literaria, op. cit., pp. 45-47. 
Es esta predilección por personajes históricos destacados, no sólo en la novela sino también en el ensayo, el teatro o la poesía hispanoamericanos, que se inicia en el siglo XIX ${ }^{5}$ y pervive hasta las manifestaciones literarias más recientes ${ }^{6}$, la que justificó la idea de dedicar un espacio amplio de reflexión en torno a este tema, centrado en el que es nuestro objeto de estudio como grupo de investigación, es decir, circunscribiendo el ámbito de análisis al período precolombino y colonial, a pesar de la importancia que figuras posteriores han alcanzado en la literatura hispanoamericana.

De este modo, el tratamiento literario e ideológico de personajes claves de la historia del continente (de Nezahualcóyotl a Cristóbal Colón, de Bartolomé de las Casas a Lope de Aguirre, de Hernán Cortés a Alonso de Ercilla, entre otros) centra la atención de un conjunto de trabajos que se abre además hacia figuras aparentemente secundarias, pero recuperadas por la literatura hispanoamericana desde el siglo XIX (pensemos en el náufrago traductor de Cortés Jerónimo de Aguilar o en la india Liropeya) e incluso hacia tipos sociales que acabaron caracterizando la vida de la América Española (como el pícaro).

Evocaciones más o menos nostálgicas, mucho más subordinadas a las exigencias de su tiempo de lo que se ha pretendido por parte de la crítica (como las de Ricardo Palma o los colonialistas mexicanos de principios del XX) se analizan en el presente volumen junto a otras más recientes que insisten en lugares ya comunes de la reflexión identitaria (por ejemplo, el tratamiento de Gonzalo Guerrero como símbolo del mestizaje), o que abordan de forma irónica y desmitificadora a las grandes figuras del pasado desde planteamientos literarios que podrían definirse como postmodernos ${ }^{7} \mathrm{o}$, si se prefiere, «postcoloniales» ${ }^{8}$.

Más allá de la variedad de personajes y obras abordados, que es fruto de un intento de ampliar el objeto de estudio habitual en los trabajos sobre el tratamiento literario de las figuras históricas en América Latina (no sólo por lo que respecta a las figuras en sí, sino también a los géneros y a los movimientos literarios examinados), nuestro propósito ha sido sobre todo el de abrir perspectivas de análisis respecto a este ámbito temático que continúa siendo fundamental para una literatura permanentemente vinculada (al menos en una línea muy relevante de su producción) a una indagación identitaria del pasado.

Si dicho propósito se ha logrado, será sin duda gracias al rigor y a la complicidad con nuestro proyecto mostrados por los investigadores que han colaborado en este monográfico. A todos ellos, mi más sincero agradecimiento.

5 Aunque supone a su vez una continuidad, con distinto propósito, respecto al tratamiento de la materia histórica en la tradición española, y más concretamente en el teatro del Siglo de Oro, sobre todo por lo que respecta al tratamiento del tema de la Conquista (cf. Francisco Ruiz Ramón, América en el teatro clásico español. Estudio y textos, Pamplona, Universidad de Navarra, 1993 y Giuseppe Bellini, Re, dame e cavalieri. Rustici, santi e delinquenti. Studi sul teatro spagnolo e americano del Secolo Aureo, Roma, Bulzoni, 2001, pp. 155-231).

6 Recordemos que uno de los rasgos caracterizadores, según Menton, de la nueva novela histórica latinoamericana es precisamente la ficcionalización de «las personalidades históricas más destacadas» (Seymour Menton, La nueva novela histórica de América Latina, 1979-1992, México, FCE, 1993, p. 43).

7 Véase, entre otros, Cristina Pons, Memorias del olvido. Del Paso, García Márquez, Saer y la novela histórica de fines del siglo XX, México, Siglo XXI, 1996; Amalia Pulgarín, Metaficción bistoriográfica: la novela bistórica en la narrativa hispánica postmodernista, Madrid, Fundamentos, 1995; o Beatriz Rizk, "La problematización de la Historia», en Posmodernismo y teatro en América Latina: teorías y prácticas en el umbral del siglo XXI, Madrid, Iberoamericana Frankfurt am Main, Vervuert, 2001, pp. 61-92.

8 Cf. Walter Mignolo, «Occidentalización, imperialismo, globalización: herencias coloniales y teorías postcoloniales», Revista Iberoamericana, LXI:170-171 (enero-junio 1995), pp. 27-40. 